\title{
Ichthyofauna of the Carrapato, Mutum and Caba Saco streams (Araguaia River Basin), Serra dos Carajás region, southeastern Pará, Brazil
}

\author{
Patrícia Giongo ${ }^{1 *}$, Wagner Martins Santana Sampaio ${ }^{2}$, Frederico Belei ${ }^{2}$, Fabricia Kohler de Carvalho ${ }^{1}$, \\ Anderson Fernandes ${ }^{1}$ and Jorge Abdala Dergam ${ }^{2}$ \\ 1 Universidade do Estado de Mato Grosso, Departamento de Ciências Biológicas. CEP 36570-000. Tangará da Serra, MT, Brasil. \\ 2 Universidade Federal de Viçosa, Departamento de Biologia Animal. CEP 36570-000. Viçosa, MG, Brasil. \\ * Corresponding author. E-mail: patricia_giongo@yahoo.com.br
}

\begin{abstract}
The ichthyofaunistic studies from the Tocantins-Araguaia River Basin are mainly concentrated in the main channel of the Araguaia and Tocantins rivers, due to faunal studies required for hydroelectric projects. Brooks and streams are usually neglected, though they represent the habitats most threatened by human activities. These small water courses present a great diversity of fishes, and they also have high rates of endemic species. The study was conducted from December 2009 to January 2010. For the inventory, the methodology used was the Rapid Assessment Program (RAP). In each sampled area three types of data collection were utilized: open interviews with local fishermen, naked eye fish surveying, and fishing with cast nets and gill nets. This study aimed to identify the main fish species that occur in the Mutum and Caba Saco streams, that form the Pau D'Arco River, and in the Carrapato Stream that flows to the Preto River, both belonging to the Araguaia River Basin.
\end{abstract}

\section{INTRODUCTION}

The Neotropical ichthyofauna is dominated by fishes that have a relatively old association with freshwater habitats (Lovejoy et al. 2006). The Araguaia River is part of the Tocantins-Araguaia River basin which is one of the major river systems in South America (Lundberg 1998). Its complex geomorphological and climatic formation has an intrinsic relation to the fact that the drainage area includes major phytogeographic regions such as Cerrado, Amazon Forest and palm three forest (Mata de Cocais), thereby concentrating an important biodiversity, with a high level of endemism and outstanding natural value (Zuanon 2001; Dias et al. 2000; Latrubesse and Stevaux 2006).

Fish fauna studies from the Tocantins-Araguaia River basin are mostly concentrated in the in the main river channels of this basin, some of them in the upper Araguaia region (Lowe McConnel 1991; Venere et al. 1999; BeneditoCecilio et al. 2004; Melo et al. 2004; Silva et al. 2009). Other studies focused the lower Tocantins region, mainly due to ichthyofaunistic studies related to the construction of Tucuruí Dam and other hydroelectric projects in the region (Santos et al. 1984; Carvalho and Merona 1986; Camargo and Petrere-Jr. 2004; Santos et al. 2004; Merona et al. 2010). In this vast region, studies on the freshwater fish communities of brooks and streams have been rather neglected, although they deserve special attention, also because they are the most affected and threatened by human activities (Agostinho et al. 2005; Barletta et al. 2010; Nogueira et al. 2010). Buckup (1999) and Sá et al. (2003) highlighted the diversity of fish that these small water courses present, indicating high levels of endemic and/or rare species. These biotic characteristics of the streams justify the urgency of studying the ichthyofauna that occurs in these streams (Buckup 1999).
There is an urgent need of ichthyofaunal studies in the region of the Araguaia River and its tributaries, as they form one of the most important river systems of South America and also because of several other aspects already presented, which makes this area an interesting spot for water resources and aquatic biota diversity studies (Dias et al. 2000). Sá et al. (2003) emphasize the importance of the streams from the Cerrado biome, which represents a considerable part of the Araguaia River basin.

This study aims to inventory, through Rapid Assessment Program (RAP), the fish fauna from the Carrapato, Caba Saco and Mutum streams, which form the Pau D'Arco River (Arraia River micro-basin, Araguaia River basin) and the Preto River (Preto River micro-basin, Araguaia River basin) in the Serra dos Carajás region, in the state of Pará.

\section{MATERIALS AND METHODS \\ Study Site}

The collections were held at the Araguaia River basin, in the Caba Saco, Mutum (tributaries of Pau D'Arco River) and Carrapato (tributary of Preto River) streams (Figure 1), in the municipalities of Redenção and Santa Maria das Barreiras, in the Serra dos Carajás region, southeastern Pará. The collections were held under the IBAMA (Instituto Brasileiro do Meio Ambiente e dos Recursos Naturais Renováveis) permit number: 154/2007.

\section{Data collection}

The methodology used was a fast inventory (RAP Rapid Assessment Program) following Latini and Petrere (2004) with modifications. Four visits to each sample area were made between December 2009 and January 2010. In each visit, four types of data collection were used: open interviews with local fishermen; naked eye fish surveying 
on the riverside; fishing with gill nets; and fishing with $15 \mathrm{~mm}$ - mesh cast nets. The gill nets were set in groups of six at a time, all of them having the same length (10 meters) and height (1.6 meters), and mesh sizes 15, 20, 30, 40, 50 and $60 \mathrm{~mm}$, measured between adjacent knots (which allows the capture of most small size fish species). The nets were set randomly so they would reach several distinct habitat physiognomies. All nets were placed for 30 minutes. The use of such nets for this time interval ensured identical collection efforts for all sampled areas, totalizing $48 \mathrm{~m}^{2}$ /hour (6 nets x 10 meters long x 1.6 meters high $\times 0.5$ hours) in each station. The cast nets were operated using five random releases in each sample site.

\section{Data analysis}

The collected fishes were taken to the Laboratório de Sistemática Molecular de Vertebrados, at the Universidade Federal de Viçosa (UFV) to be identified using specific taxonomic keys and identification guides (Géry 1969; Santos et al. 1984, 2004; Melo et al. 2005; Britski et al. 2007) and consulting specialists. The captured fishes were identified and deposited at the Laboratório de Sistemática Molecular de Vertebrados Beagle, at the Universidade Federal de Viçosa. Fishes with measurements inferior to $0.4 \mathrm{~m}$ and $1 \mathrm{~kg}$ were fixed, larger specimens were returned alive to the streams, with the exception of unique or rare ones. All fishes were weighed, measured and photographed.

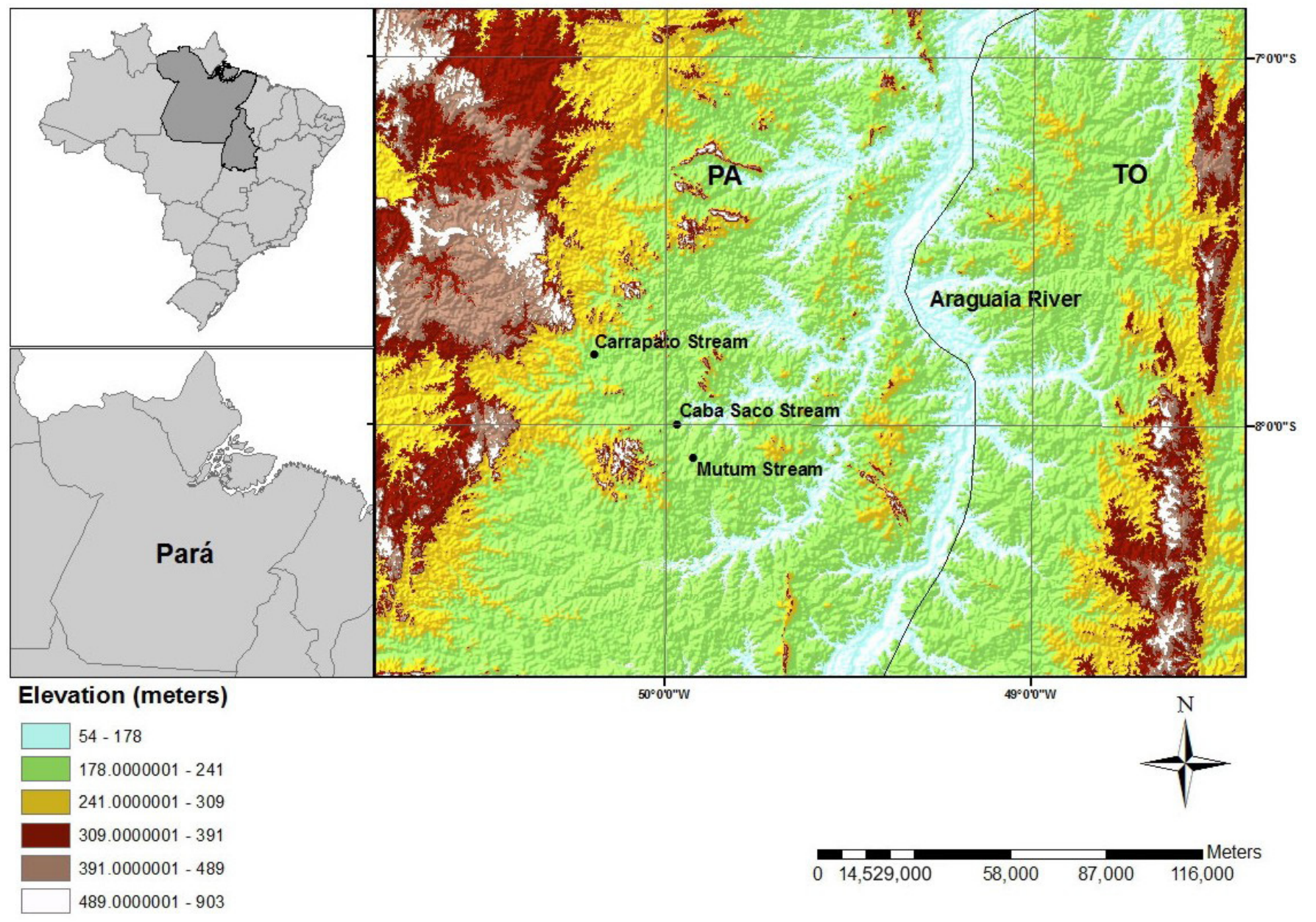

FIGURE 1. Map of the study region - localization of the rivers and the position of the sampling sites.

\section{RESULTS AND Discussion}

The fishes captured and identified using a combination ofmethodologies called RAP (Latini and Petrere 2004) in the Caba Saco, Mutum and Carrapato streams, were distributed in 37 species, in 33 genera from 14 families and five orders: Characiformes (Characidae, Erythrinidae, Anostomidae, Hemiodontidae, Prochilodontidae, Curimatidae, Acestrorhynchidae, Cynodontidae, Ctenoluciidae), Siluriformes (Loricariidae, Pimelodidae), Perciformes (Cichlidae), Synbranchiformes (Synbranchidae), and Rajiformes (Potamotrygonidae) (Table 1). Among these families, Characidae (Characiformes) and Cichlidae (Perciformes) represented the greater species richness, with 13 and six species, respectively. Siluriformes were only represented by four species belonging to two families (Loricariidae and Pimelodidae), while the Synbranchidae and Potamotrygonidae by a single species, each. Other studies in the Tocantins-Araguaia River basin also report the order Characiformes as the most diverse, followed by Siluriformes (Aloísio et al. 2005; Melo et al. 2005; Lucinda et al. 2007) and not by Perciformes as occurred in this study.

Carrapato Stream concentrated a higher level of richness and abundance that may be related to its greater water volume and the strong influence of major rivers, such as the Preto and Araguaia (Table 1). This fact justifies the presence of large species like Pseudoplatystoma fasciatum, Hemisorubim platyrhynchos and Potamotrygon motoro, 
TABLE 1. Species surveyed with RAP protocols in some streams of the Araguaia Basin. Popular names; taxonomic classification; sample station: 1Carrapato Stream, 2- Caba Saco Stream, 3- Mutum Stream; Species category: N-native, RI- Reportedly introduced, CR- critically endangered (Rosa and Lima 2008); method of collection: G - Gill net, C - Casting net, IN - Interview, NS - Naked eye surveying.

\begin{tabular}{|c|c|c|c|c|}
\hline TAXON & LOCAL NAME & $\begin{array}{l}\text { SAMPLE } \\
\text { STATION }\end{array}$ & $\begin{array}{c}\text { SPECIES } \\
\text { CATEGORY }\end{array}$ & METHOD \\
\hline \multicolumn{5}{|l|}{ CHARACIFORMES } \\
\hline \multicolumn{5}{|l|}{ Characidae } \\
\hline Astyanax bimaculatus (Linnaeus, 1758) & Lambari, tambiú & $1,2,3$ & $\mathrm{~N}$ & $\mathrm{G} / \mathrm{C}$ \\
\hline Tetragonopterus argenteus Cuvier, 1816 & Pataca & 1 & $\mathrm{~N}$ & $\mathrm{G} / \mathrm{C}$ \\
\hline Moenkhausia sp. & Piaba & $1,2,3$ & $\mathrm{~N}$ & G \\
\hline Brycon sp. & Piabanha & 1 & $\mathrm{~N}$ & G \\
\hline Chalceus epakros Zanata and Toledo-Piza, 2004 & Piaba do rabo vermelho & 1 & $\mathrm{~N}$ & G \\
\hline Triportheus trifurcatus (Castelnau, 1855). & Sardinha & 1 & $\mathrm{~N}$ & $\mathrm{G}$ \\
\hline Roeboides affinis (Günther, 1868) & Corcunda & $1,2,3$ & $\mathrm{~N}$ & $\mathrm{G} / \mathrm{C}$ \\
\hline Mylossoma duriventre (Cuvier, 1818) & Pacu & 1 & $\mathrm{~N}$ & G \\
\hline Piaractus brachypomus (Cuvier, 1818) & Caranha & 1 & $\mathrm{~N} / \mathrm{RI}$ & IN \\
\hline Serrasalmus geryi Jégu and Santos, 1988 & Piranha Branca & 1 & $\mathrm{~N}$ & G \\
\hline Serrasalmus manueli (Fernández-Yépez and Ramírez, 1967) & Xupita & 1 & $\mathrm{~N}$ & G \\
\hline Serrasalmus rhombeus (Linnaeus, 1766) & Piranha preta & 1,3 & $\mathrm{~N}$ & G \\
\hline Pygocentrus nattereri Kner, 1858 & Piranha vermelha & 1 & $\mathrm{~N}$ & G \\
\hline \multicolumn{5}{|l|}{ Erythrinidae } \\
\hline Hoplerythrinus unitaeniatus (Spix and Agassiz, 1829) & Jeju & $1,2,3$ & $\mathrm{~N}$ & G \\
\hline Hoplias malabaricus (Bloch, 1794) & Traíra & $1,2,3$ & $\mathrm{~N}$ & G \\
\hline \multicolumn{5}{|l|}{ Anostomidae } \\
\hline Leporinus friderici (Bloch, 1794) & Piau cabeça gorda & $1,2,3$ & $\mathrm{~N}$ & $\mathrm{G} / \mathrm{C}$ \\
\hline Schizodon vittatus (Valenciennes,1850) & Piau vara & 1 & $\mathrm{~N}$ & G \\
\hline \multicolumn{5}{|l|}{ Prochilodontidae } \\
\hline Prochilodus nigrans Agassiz, 1829 & Papa terra & 1 & $\mathrm{~N} / \mathrm{RI}$ & IN \\
\hline \multicolumn{5}{|l|}{ Curimatidae } \\
\hline Curimata cyprinoides (Linnaeus, 1766) & Branquinha & $1,2,3$ & $\mathrm{~N}$ & G \\
\hline Steindachnerina amazonica (Steindachner, 1911) & Branquinha & $1,2,3$ & $\mathrm{~N}$ & G \\
\hline Steindachnerina gracilis Vari and Vari, 1989 & Branquinha & $1,2,3$ & $\mathrm{~N}$ & G \\
\hline \multicolumn{5}{|l|}{ Acestrorhynchidae } \\
\hline Acestrorhynchus falcatus (Bloch, 1794) & Cachorrinho & 3 & $\mathrm{~N}$ & G \\
\hline \multicolumn{5}{|l|}{ Cynodontidae } \\
\hline Rhaphiodon vulpinus Spix and Agassiz, 1829 & Chacorra-facão & 1 & $\mathrm{~N}$ & G \\
\hline \multicolumn{5}{|l|}{ Ctenoluciidae } \\
\hline Boulengerella cuvieri (Agassiz, 1829) & Bicuda & 1 & $\mathrm{~N}$ & G \\
\hline \multicolumn{5}{|l|}{ Hemiodontidae } \\
\hline Hemiodus unimaculatus (Bloch, 1794) & Voador & 1 & $\mathrm{~N}$ & G \\
\hline \multicolumn{5}{|l|}{ PERCIFORMES } \\
\hline \multicolumn{5}{|l|}{ Cichlidae } \\
\hline Astronotus ocellatus (Agassiz, 1831) & Cara-açú & 1 & $\mathrm{~N} / \mathrm{RI}$ & $\mathrm{G} / \mathrm{C}$ \\
\hline Cichla monoculus Spix and Agassiz, 1831 & Tucunaré de crista & 1 & $\mathrm{~N} / \mathrm{RI}$ & IN \\
\hline Cichla ocellaris Bloch and Schneider, 1801 & Tucunaré & 1 & $\mathrm{~N} / \mathrm{RI}$ & $\mathrm{G}$ \\
\hline Crenicichla cyclostoma Ploeg 1986 & Joaninha & $1,2,3$ & $\mathrm{~N} / \mathrm{CR}$ & G \\
\hline Geophagus surinamensis (Bloch, 1791) & Rola - Pedra & $1,2,3$ & $\mathrm{~N}$ & G \\
\hline Aequidens duopunctatus Haseman, 1911 & Cará & $1,2,3$ & $\mathrm{~N}$ & $\mathrm{C}$ \\
\hline \multicolumn{5}{|l|}{ SILURIFORMES } \\
\hline \multicolumn{5}{|l|}{ Loricariidae } \\
\hline Hypostomus sp. & Cascudo & $1,2,3$ & $\mathrm{~N}$ & G \\
\hline \multicolumn{5}{|l|}{ Pimelodidae } \\
\hline Pimelodus blochii Valenciennes, 1840 & Mandi & $1,2,3$ & $\mathrm{~N} / \mathrm{RI}$ & G \\
\hline Hemisorubim platyrhynchos Valenciennes, 1840 & Jiripoca & 1 & $\mathrm{~N} / \mathrm{RI}$ & IN \\
\hline Pseudoplatystoma fasciatum (Linnaeus, 1766) & Pintado & 1 & $\mathrm{~N} / \mathrm{RI}$ & IN \\
\hline \multicolumn{5}{|l|}{ SYNBRANCHIFORMES } \\
\hline \multicolumn{5}{|l|}{ Synbranchidae } \\
\hline Synbranchus marmoratus Bloch, 1785 & Mussum & $1,2,3$ & $\mathrm{~N}$ & NS \\
\hline \multicolumn{5}{|l|}{ MYLIOBATIFORMES } \\
\hline Potamotrygonidae & & & & \\
\hline Potamotrygon motoro (Muller and Henle, 1841) & Arraia de fogo & 1 & $\mathrm{~N}$ & NS \\
\hline
\end{tabular}


which were found only in this stream, in addition to the occurrence of species from large rivers that rarely appear in small tributaries, except during the spawning season (e g. Hemiodus unimaculatus, Triportheus trifurcatus and Schizodon vittatus) (Buckup 1999; Melo et al. 2005). The Mutum and Caba Saco streams had a small portion of the fish species present in the Carrapato stream fish, probably due to the small size of these streams, with high seasonal fluctuations of water volume and therefore do not sustain the large species (Esteves and Aranha 1999).

Through interviews, it was evident that the region is subjected to an intense process of native fish aquaculture activities that may explain the presence of large fish species in these small streams. This introduction occurs mainly by accidental events, such as disruption of dams and artificial ponds. Local fishermen indicated the following species as being recently introduced: Caranha (Piaractus brachypomus), Tucunaré (Cichla ocellaris, C. monoculus), Papa-terra (Prochilodus nigrans), Cara-açú (Astronotus ocellatus), Pintado (Pseudoplatystoma fasciatum), and Jiripoca (Hemisorubim platyrhynchos). The situation described may be worrisome: although all the surveyed species were native to the Tocantins-Araguaia River Basin, the effects of species introduction in habitats or river stretches where they do not occur naturally (therefore disrupting original community composition, as explained by the River Continuum Concept (Vannote et al. 1980). This faunal mixing goes against the currently accepted concept that native species are less harmful than exotics. When a lowland species is introduced in higher reaches of the same drainage it may find some conditions that usually favor invasive species success: lack of predators or diseases, low diversity and vacant niches (Pimm 1989).

This study reported the presence of an endangered species, commonly known as the Joaninha (Crenicichla cyclostoma), in the three streams mentioned (Rosa and Lima 2008; Albernaz and Avila-Pires 2009). Rosa and Lima (2008) indicated the last recordings of this species in the 1980s, before and shortly after the construction of the Hydroelectric Dam in Tucuruí. The specimens captured in this study were collected in possible home range indicated by Rosa and Lima (2008) in the Araguaia basin, at the end of the middle portion and the start of the lower portion of this basin. In the Serras dos Carajás region, the main threats to this species are habitat destruction for mineral exploration, deforestation and hydroelectric dams (Casatti 2010). Nogueira et al. (2010) reported that the AraguaiaTocantins River Basin has 22 critical areas containing approximately 101 species, all of which are currently living in restricted ranges and that could potentially be included in the endangered species lists. Ichthyofaunal studies from the Amazon River Basin and the river systems connected to it, as the Tocantins-Araguaia River Basin, are still very scarce, especially the ones focusing habitats such as small streams and brooks. Faunal inventories are essential for understanding the still largely unknown diversity of Neotropical fishes (Langeani et al. 2009; Casatti et al. 2010). The RAP methodology seemed to be an efficient tool for carrying out ichthyofaunal surveys, because it allows complementation of standard collecting devices (gill nets and cast nets) with naked eye surveying and interviews.
ACKNowledgments: We thank Heldo Santana Sampaio for the assistance during the collections, Linjandelson Mundoca, member and president of the Santa Maria das Barreiras City Council, for his assistance in determining the sampling areas and contacts with the local fishermen, and Wilder Santana Sampaio for allowing the collecting activities in his farms.

\section{Literature Cited}

Agostinho, A.A., S. M. Thomaz and L.C. Gomez. 2005. Conservação da biodiversidade em águas continentais do Brasil. Megadiversidade 1(1): 70-78.

Albernaz, A.L.K.M. and Avila Pires, T.C.S. (org.). 2009. Espécies Ameaçadas de Extinção e Áreas Críticas para a Biodiversidade no Pará. Belém: Museu Paraense Emilio Goeldi/Conservation International, 56 p.

Aloísio, G., F.G. Oliveira and R. Angelini. 2005. Fish, State Park of Jalapão, State of Tocantins, Brazil. Check List 1(1): 10-13.

Barletta, M., A.J. Jaureguizar, C. Baigun, N.F.Fontoura, A.A. Agostinho, V.M.F. Almeida-Val, A.L. Val, R.A. Torres, L.F. Jimenes-Segura, T. Giarrizzo, N.N. Fabré, V.S. Batista, C. Lasso, D.C. Taphorn, M.F. Costa, P.T. Chaves, J.P. Vieira and M.F.M. Corrêa. 2010. Fish and aquatic habitat conservation in South America: a continental overview with emphasis on neotropical systems. Journal of Fish Biology 76: 21182176.

Benedito-Cecilio, E., C.V. Minte-Vera, C.H. Zawadzki, C.S. Pavanelli, F.H.G. Rodrigues and M.F. Gimenes. 2004, Ichthyofauna from the Emas National Park Region: Composition and Structure. Brazilian Journal Biology 64(3): 371-382.

Britski, H.A., K.Z.S. Silimon and B.S Lopes. 2007. Peixes do Pantanal: manual de identificação. 2a . ed. Brasília: Embrapa. 230 p.

Buckup, P.A. 1999. Sistemática e biogeografia de peixes de riachos; p. 91-138 In E.P. Caramaschi, R. Mazzoni and P.R. Peres (ed.). Ecologia de peixes de riachos. Rio de Janeiro: PPGE-UFRJ, Série Oceologia Brasiliensis.

Camargo, S.A.F. and M. Petrere-Júnior. 2004. Análise de risco aplicada ao manejo precaucionário das pescarias artesanais na região do Reservatório da UHE-Tucuruí (Pará-Brasil). Acta Amazonica 34(3): 473-485.

Carvalho, J.L. and B. Merona. 1986. Estudo sobre dois peixes migratórios do baixo Tocantins antes do fechamento da barragem de Tucuruí. Amazoniana 9(4): 595-607.

Casatti, L. 2010. Alterações no Código Florestal Brasileiro: Impactos potenciais sobre a ictiofauna. Biota Neotropical 10(4): 30-34.

Casatti, L., R.M. Romero, F. B. Teresa, J. Sabino and F. Langeani. 2010. Fish community structure along a conservation gradient in Bodoquena Plateau streams, central west of Brazil. Acta Limnologica Brasiliensia, 22: 50-59.

Dias, A., E. Latrubesse and M. Galinkin. 2000. Projeto corredor ecológico Bananal-Araguaia. Brasília: Ministério do Meio Ambiente. 120 p.

Esteves, K.E. and J. M.R. Aranha.1999. Ecologia trófica de peixes de riachos. p. 157-182 In E.P. Caramaschi, R. Mazzoni and P.R. Peres (ed.). Ecologia de peixes de riachos. Rio de Janeiro: PPGE-UFRJ, Série Oceologia Brasiliensis.

Géry. J. 1969. The fresh-water fishes of South America; p. 828-848 In J. Fitkau; J. Illies; H. Klinge, G.H. Schwabe and H. Sioli (ed.). Biogeography and ecology in South America. The Hague: W. Junk N.V. Publishers.

Hansen, M.M., D.E. Ruzzante, E. E. Nielsen and K.L.D. Mensberg. 2001. Brown trout (Salmo trutta) stocking impact assessment using microsatellite DNA markers. Ecological Applications 11:148-160.

Langeani, F., P.A. Buckup, L.R. Malabarba, L.H.R. Pydaniel,C.A.S. Lucena, R.S Rosa J.A.S. Zuanon, Z.M.S.Lucena, M.R. Britto,O.T. Oyakawa and G.Gomes-Filho. 2009. Peixes de Água Doce; p. 209-230 In R.M. Rocha and W.A.P. Boeger. (org.). Estado da Arte e perspectivas para a Zoologia no Brasil. 1 ed. Curitiba: Editora da UFPR.

Latini, A.O. and M. Petrere. 2004. Reduction of a native fish fauna by alien species: an example from Brazilian freshwater tropical lakes. Fisheries Management and Ecology 11(2): 71-79.

Latrubesse, M.E. and C.J. Stevaux. 2006. Características físico-bióticas e problemas ambientais associados à planície aluvial do Rio Araguaia, Brasil Central. UnG - Geociências 5(1): 65-73.

Lundberg, J.G., L.G. Marshall, J. Guerrero, B. Horton, M.C.S.L. Malabarba and F. Wesselingh. 1998. The stage for Neotropical fish diversification: A history of tropical South America rivers; p. 13-48 In L.R. Malabarba, R.E. Reis, R.P. Vari, Z.M.S. Lucena and C.A.S. Lucena (ed.). Phylogeny and Classification of Neotropical Fishes. Edipucrs, Porto Alegre, Brasil.

Lovejoy, N.R., J.S. Albert and G.R. Crampton. 2006. Miocene marine incursions and marine/freshwater transitions: Evidence from Neotropical fishes. Journal of South American Earth Sciences 21: 5-13.

Lowe-McConnell, R.H. 1991. Natural history of fishes in Araguaia and Xingu Amazonian tributaries. Serra do Roncador, Mato Grosso, Brazil. Ichthyological Exploration of Freshwaters 2:63-82.

Lucinda, P.H., I.S. Freitas, A.B. Soares, E.E. Marques, C.S. Agostinho and R.J. 
Oliveira. 2007. Fish, Lajeado Reservoir, rio Tocantins drainage, State of Tocantins, Brazil. Check List 3(2): 70-83.

Melo, C.E., F.A. Machado and V. Pinto-Silva. 2004. Feeding habits of fish from a stream in the savanna of Central Brazil, Araguaia Basin. Neotropical Ichthyology 2(1): 37-44.

Melo, C.E., J.D. Lima, T.L. Melo and V. Pinto-Silva. 2005. Peixes do rio das Mortes: identificação e ecologia das espécies mais comuns. Cuiabá: Unemat. $147 \mathrm{p}$.

Merona, B., A. Juras, G. M. Santos and I. Cintra. 2010. Os peixes e a pesca no baixo Rio Tocantins: vinte anos depois da UHE Tucuruí. 1. ed. Brasilia: Eletronorte. $218 \mathrm{p}$.

Nogueira, C., P.A. Buckup, N.A. Menezes, O.T. Oyakawa, T.P. Kasecker, M.B. Ramos-Neto and J.M.C. Silva. 2010. Restricted-Range Fishes and Conservation of Brazilian Freshwaters. Plos-One 5(6):1-10.

Penzack, T. 1999. Impact of brown trout on native fish communities in the Pilica River catchment (Poland). Environmental Biology of Fishes 54: $237-252$.

Pimm, S.L. 1989. Theories of predicting success and impact of introduced species; p. 351-367 In J.A. Drake, F. DiCastri, R.H. Groves, F.J. Kruger, H.A. Mooney, M. Rejmánek and M.H. Williamson (ed.). Biological Invasions: A Global Perspective. Chichester: John Wiley and Sons.

Rhymer J.M. and D. Simberloff. 1996. Extinction by hybridization and introgression. Annual Review of Ecology and Systematics 27:83-109.

Rosa, R.S. and F.C.T. Lima. 2008. Os peixes brasileiros ameaçados de extinção; p. 9-19 In A.B.M. Machado, G.M. Drummond and A.P. Paglia (org.). Livro vermelho da fauna brasileira ameaçada de extinção, Vol. II. $2^{a}$ ed. Brasília: Ministério do Meio Ambiente.

Sá, M.F.P., N. Fenerich-Verani and E.N. Fragoso. 2003. Peixes do Cerrado em perigo. Ciência Hoje 34(200): 68-71.

Santos, G.M., M. Jegu and B. Merona. 1984. Catálogo dos peixes comerciais do baixo rio Tocantins. Brasilia: Eletronorte. 86 p.

Santos, G.M., A.A. Juras, B. Merona and M. Jegu. 2004. Peixes do baixo rio Tocantins. 20 anos depois da Usina Hidrelétrica Tucuruí. Brasilia: Eletronorte. 215 p.

Silva, E.L., L. Centofante and C.S. Miyazawa. 2009. Análise morfométrica em Thoracocharax stellatus (Kner, 1858) (Characiformes, Gasteropelecidae) proveniente de diferentes bacias hidrográficas Sul-americanas. Biota Neotropica 9(2): 71-76.

Utter, F.M. 2003. Genetic impacts of fish introductions; p. 357-378 In E.M. Hallerman (ed), Population Genetics: Principles and Applications for Fisheries Scientists. Bethesda: American Fisheries Society.

Vannote, R.L., G.W. Minshall, K.W. Cummins, J.R. Sedell and C.E. Cushing. 1980. The river continuum concept. Canadian Journal of Aquatic Fisheries and Aquatic Science 37: 130-137.

Venere, P.C., C.S. Miyazawa and P.M. Galetti Junior. 1999. New cases of supernumerary chromosomes in characiform fishes. Genetics and Molecular Biology 22(3): 345-349.

Zuanon, J.A. S. 2001. Estudo das espécies ícticas e opções de manejo piscícola no parque estadual do Cantão - estado do Tocantins. Manaus: Fundação Djalma Batista - Convênio FDB / INPA. 221 p.

RECEIVED: October 2010

LAST REVISED: July 2011

ACCEPTED: July 2011

PUBLISHED ONLINE: July 2011

EDITORIAL RESPONSIBILITY: Sergio Maia Queiroz Lima 